\title{
Sectoral Effects of Reductions in NATO Military Expenditures in the Major Industrialized and Developing Countries
}

JON D. HAVEMAN

Purdue University, West Lafayette, IN, U.S.A.

ALAN V. DEARDORFF

University of Michigan, Ann Arbor, MI, U.S.A.

ROBERT M. STERN

University of Michigan, Ann Arbor, MI, U.S.A.

Key words: military expenditures, unilateral/multilateral reductions, sectoral effects

\begin{abstract}
We use the Michigan Model of World Production and Trade to assess the sectoral effects of (1) a 25 percent unilateral reduction of military expenditures in the individual NATO countries and (2) a 25 percent multilateral reduction of military expenditures in all of the NATO countries combined. Our principal findings suggest that the overall effects of the unilateral and multilateral reductions are not substantial and that the results of the two reductions are qualitatively similar. The sectoral results, which are also broadly similar in the two experiments, suggest that sectors such as basic metals and metal products, durable goods, and community, social, and personal services might be in need of transitional adjustment assistance for displaced workers in the event that the reductions in military expenditures would in fact be carried out.
\end{abstract}

With the end of the Cold War and attendant fragmentation of the former Soviet Union, Soviet military influence no longer poses a grave threat to international security. The destruction of Iraq's military capabilities and the opening of the Israeli-Arab dialogue may also have served to reduce the potential for large-scale conflict in the Middle East. The confluence of these remarkable changes suggests that there may now be considerable scope for reduction in military expenditures in the NATO member countries. Accordingly, there is interest in the aggregate and 
sectoral impacts that might be experienced in the world's major industrialized and developing countries if significant reductions in military expenditures indeed prove to be possible. ${ }^{1}$

Using the computational general equilibrium (CGE) Michigan Model of World Production and Trade, we first investigate the impact of a 25 percent unilateral reduction in military spending for each NATO country. Then, we investigate the impact of a 25 percent multilateral reduction in military spending in all of the NATO countries combined. An important advantage in using the Michigan Model is that it incorporates the effects of international trade and allows for price and exchange rate responses as well as primary input substitution possibilities. The Michigan Model thus provides a richer insight into the sectoral effects stemming from changes in military expenditures than has been provided by earlier research. ${ }^{2}$

Previous work has generally compensated for changes in military expenditures by changing nonmilitary government purchases. However, as discussed in Haveman, Deardorff, and Stern (1992), prior episodes of substantial reductions in U.S. military expenditures did not follow this path. We therefore assumed in our aforementioned work that reductions in government military spending were compensated by shifting expenditures to various components of final demand, including: (1) nondefense government spending; (2) private consumption; (3) investment; and (4) proportional reallocation across all of the foregoing expenditure components. In this paper, we adopt the last of these expenditure shifts.

Our paper is structured as follows. In Section 1, we present a brief description of the Michigan Model and discuss elements of it that are of particular importance to our study. In Section 2, we discuss some assumptions underlying our computational experiments, and in Section 3, some theoretical considerations that pertain to our experiments. The computational results are presented in Section 4. Our conclusions and implications of the results are discussed in Section 5.

\section{Overview of the Michigan Model}

The theoretical structure and equations of the Michigan Model are described in detail in Deardorff and Stern (1986, pp. 9-36 and 235$247 ; 1990$, pp. 9-35). For our purposes here, we present a brief overview of the model and call attention to some of its features that are pertinent to the present analysis. 
In designing the Michigan Model, the objective was to take into account as many of the microeconomic interconnections among industries and countries as possible. This disaggregated general equilibrium framework enables us to examine a variety of economic issues that most other computational models cannot address, either because they are too highly aggregated, or because they are specified only in partial equilibrium terms.

\subsection{Data and parameters}

The version of the model used here includes 23 tradable and six nontradable industries in 18 industrialized and 16 developing countries, plus an aggregate sector representing the rest of the world. ${ }^{3}$ We use a base of 1980 data on trade, production, and employment for all 34 countries, plus constructed measures of the coverage of nontariff barriers (NTBs) for the 18 industrialized countries.

The import and export data are adapted from United Nations trade tapes, with concordances that relate the Standard International Trade Classification (SITC) to our version of the International Standard Industrial Classification (ISIC) categories. Information on the gross value of production and employment by ISIC sector is directly calculated or estimated from the United Nations Yearbook of Industrial Statistics, Organization for Economic Cooperation and Development (OECD) publications on national accounts and labor statistics, and various national statistical sources.

Our input-output coverage currently includes national tables for all of the industrialized countries of the model except Switzerland. They are taken from various years ranging from 1975 for Japan and members of the EC-9 to 1982 for Finland. The 1977 table for the United States is applied to Switzerland. For the developing countries, our coverage currently includes separate tables for Brazil (1975), Chile (1977), India (1973), Israel (1977), Korea (1980), Mexico (1980), Portugal (1981), Singapore (1973), Spain (1980), Taiwan (1986), Turkey (1973), and Yugoslavia (1976). The Brazilian table is applied to the remaining developing countries. The use of national tables allows for differences in technology among the countries included in the model. ${ }^{4}$

In general, the coefficients of explanatory variables that appear in the model are calculated from data on production, trade, and employment by sector in each country, from the input-output matrices, and from relevant published estimates of demand and substitution elasticities. 


\subsection{The model structure}

The model is best thought of as composed of two parts: the country system and the world system. The country system contains separate blocks of equations for the individual tradable and nontradable sectors for each country, and the world system contains a single set of equations for individual tradable sectors for the world as a whole. The country blocks are used first to determine each country's supplies and demands for goods and currencies on world markets as functions of world prices, exchange rates, and exogenous variables. The supply and demand functions for each country are then combined to provide the input to the world system that permits world prices and exchange rates to be determined.

The world system is the less complicated of the two systems. We start with the export supply and import demand functions from the country equations, which depend on world prices and exchange rates. To get world prices, we add these supplies and demands across all countries and set the difference equal to net demand from the rest of the world. To obtain exchange rates, where these are flexible, we add the value of excess supply across all of the industries in a country and equate the resulting trade balance to an exogenously given capital flow. Once we obtain the world prices for each tradable industry and the exchange rate for each country, we enter them back into the separate country blocks in order to determine the rest of the relevant country-specific variables.

\subsection{Description of the exogenous change variables}

The Michigan Model can be used to analyze price and quantity responses to a number of exogenous changes in the world trading environment. These changes can be represented through the use of some 18 exogenous variables, each referring to a different change in the trading environment. These variables include, for example, changes in import tariffs, changes in export taxes, changes in exchange rates where they are exogenous, and changes in the aforementioned capital flows.

For the current analysis, however, we use only two exogenous change variables, both representing particular kinds of shifts in demand. One is an inter-industry shift variable, denoted $e \alpha$, that describes a reallocation of final demand across industries. The other is an intra-industry shift variable, denoted $\mathrm{e} \beta$, that captures a shift of demand within an industry from home-produced goods to imports. A formal statement of the roles that these two shift parameters play in the Michigan Model is available from the authors on request. 


\section{Computational experiments and assumptions}

In periods when military expenditures are reduced, the question naturally arising is, what happens to nonmilitary expenditures? There are principally three macroeconomic policies that could accompany a reduction in military expenditures: (1) increase other spending; (2) reduce taxes; or (3) reduce government borrowing. ${ }^{5}$ That is, first, policymakers could redistribute the expenditure to other forms of government spending - for example, to human or physical resources. Second, the reduction in expenditure could be matched by a reduction in government receipts, thus increasing civilian consumption. Finally, the reduced expenditure could be used to reduce a budget deficit or increase a surplus, reducing interest rates and thereby stimulating investment. As Steuerle and Wiener (1990) have noted, the three postwar periods after 1945 experienced each of these policies, but in rather different combinations.

Given that there have been a variety of macroeconomic responses to reductions in military expenditures, it is difficult to determine what the appropriate strategy should be in modeling such expenditure reductions. The reason this is important is that the effect on the sectoral composition of trade and employment due to a reduction in military spending depends crucially on the assumptions one makes about the accompanying macroeconomic policies. Because the Michigan Model does not formally allow for changes in interest rates or domestic taxes, the scenarios chosen for analyzing reductions in military expenditures are implemented by exogenously altering the composition of final demand. Thus, as already mentioned in Haveman, Deardorff, and Stern (1992), we made allowances for shifts in military spending to several categories of final demand, including consumption, investment, nonmilitary government spending, and a proportional shift across all sectors of nonmilitary final demand. In the present paper, we confine our attention to the latter case of the proportional shift.

We concentrate on two scenarios: (1) a 25 percent unilateral reduction of military expenditures in the individual NATO countries and (2) a 25 percent multilateral reduction of military expenditures in all of the NATO countries combined. ${ }^{6}$ Each scenario is based on a 25 percent reduction in the level of 1989 military expenditures in each country. These reductions are taken as a uniform percentage of military expenditures allocated to each of the 29 sectors being modelled in each country. The reduction in military expenditures is prorated proportionally to all three sectors of final demand, namely, consumption, investment, and nonmilitary government expenditure.

In interpreting the computational results presented below, it is important to note the following assumptions that have been made: 
1. The level of aggregate expenditure is constant.

2. Capital stocks are fixed for each industry, on the grounds that the time period under investigation is too short for changes in investment to be realized as additions to the capital stock.

3. Real wages are assumed to be flexible, i.e., labor markets are permitted to clear.

4. All defense expenditure is assumed to have been allocated to domestic industry.

5. Exchange rates are modeled as flexible, except for a number of developing countries.

Some of these assumptions are in need of further explanation or justification. First, the assumption that aggregate expenditure is held constant is necessary because the microeconomlc orientation of the Michigan Model makes it inappropriate for discussing macroeconomic phenomena such as the determination of aggregate expenditure or employment. A further consequence of the microeconomic nature of the model is assumption (3). Our results are all dependent on constant aggregate employment, which is assured by allowing for flexibility in real wages. There are alternative methods of maintaining constant employment, such as allowing the level of final demand to adjust appropriately, but these adjustments would de-emphasize the role played by the differences in the distribution of military spending and other sources of final demand.

Assumption (4) is designed to reflect the preference that most countries give to domestic manufacturers and suppliers when contracts are signed and purchases are made. Given this preference, we believe that the average propensity to import of the national defense establishment is significanity less than that of final and intermediate demand in the aggregate. In the absence of detailed information, we assume that the average propensity to import of the national defense establishment is equal to zero in all of the countries.

Implementation of the two policy experiments is conceptualized as a shift in the final demand for the output of each of the 29 sectors. The first step in each of the scenarios is to appropriately redistribute the reduction in military spending. These redistributions of final demand are represented in the Michigan Model as changes in the demand share parameters of the consumers' utility function. In what follows, $\alpha_{\mathrm{j}}$ will be used to represent the share of final demand attributable to purchases from sector $\mathrm{j}$. Given the nature of the model, the proportional change in these parameters is needed to reflect the shift in final demand. The proportional change variable is obtained by calculating the actual share of each sector in final demand $\left(\alpha_{0 j}, j=1, \ldots, 29\right)$ and the final demand share of each sector once the defense spending has been 
redistributed $\left(\alpha_{1 \mathrm{j}}, \mathrm{j}=1, \ldots, 29\right)$. The proportional change is then calculated as:

$$
e \alpha_{j}=\frac{d \alpha_{j}}{\alpha_{j}}=\frac{\alpha_{1 j}-\alpha_{0 j}}{\alpha_{0 j}} \quad(j=1, \ldots, 29) \text {. }
$$

In order to calculate the inter- and intra-industry shift parameters that are needed for each sector in each country, five pieces of data are required: GNP for each country, the volume of defense purchases, the distribution of GNP and defense procurement across sectors, and the share of imports in final domestic demand for each sector. Data on the share of imports in final demand were obtained from data already present in the model. The sources for the remaining data are detailed below.

The calculation of $e \alpha$, which is the percent change in demand for each sector, requires the distribution and levels of defense spending and final demand for each country. Data on aggregate military expenditures and GNP for each country for 1989 were obtained from the 1990 U.S. Arms Control and Disarmament Agency (ACDA) publication. In order to calculate the demand shift parameters for each of the 29 industries in each country, it was necessary to distribute the aggregate military expenditure and GNP data across the industries modelled. The distribution of GNP was accomplished through the use of the input-output tables already employed in the model. The aggregate obtained was distributed to replicate the share in final demand for each of the 29 sectors.

Disaggregated estimates of the distribution of defense spending were employed for the United States, Canada, the United Kingdom, and West Germany and are from The Survey of Current Business (1990), Herring (1989), Barker et al. (1990), and Filip-Kohn et al. (1980), respectively. Leontief and Duchin (1983) provide estimates of the proportion of the ACDA data on aggregate military expenditures that correspond to 12 categories. We; in turn, concorded the categories in each of the aforementioned publications to our industrial classification.

As noted above, defense purchases are assumed to be made entirely from domestic production. The shift of expenditure away from defense will therefore be accompanied by an exogenous increase in imports. As a result, we need to adjust the fraction of new expenditure that now goes towards the purchase of imported goods. We assume that each category of total demand in an industry purchases imports in the same percentages as that of final demand in that industry as a whole. ${ }^{7}$

\section{Some theoretical considerations}

Having stated some important assumptions underlying our experiments, it may be helpful to provide a theoretical discussion of some of the 
interactions that are present in the Michigan Model. This can be done with the aid of the partial equilibrium supply and demand diagrams shown in Fig. 1, assuming initially that there is a unilateral reduction in military expenditure.

The top panel of Fig. 1 shows the market for home-produced goods in a representative industry. Supply and demand in such a home market depend, of course, on the home price, but the positions of the supply and demand curves also depend on various prices of imports. This dependence is only shown in the figure for the price of the imported good in the same industry. This matters for demand because of consumer substitution, and it matters for supply because of the use of imports as inputs into production.

The bottom panel shows the markets for exports and imports within the same industry. Here the prices and quantities of exports and imports are drawn for convenience on the same axis, because in the model they are viewed as identical products in the world market. However, within the country, imports of an industry are viewed as distinct from exports, and there is no reason in general to compare them. Nonetheless, we show them being equal initially, partly for convenience and partly to enable us, even though inappropriately, to represent the process of exchange rate adjustment in this single market context.

For both exports and imports, the world price in the industry, $\mathrm{P}_{\mathrm{W}}$, is translated into domestic currency by multiplying it by the exchange rate, $R$. In the absence of any export taxes or subsidies, this gives the export price, $\mathrm{PX}_{\mathrm{X}}$. The supply of exports depends upon this price, as well as on the price in the home market, again because of the use of home market goods as inputs into production for export. ${ }^{8}$

The price facing importers, $\mathrm{P}_{\mathrm{M}}$, is also given by $R \mathrm{P}_{\mathrm{W}}$, except that it is augmented by $t$, representing the ad valorem tariff together with the tariff equivalent of any nontariff barrier that may be present. Thus, the demand curve is drawn as a function of $P_{M}$, and, again, its position depends on the home price from the other panel.

A cut in defense expenditure has two effects, as already noted. First, depending where defense expenditure was concentrated compared to the pattern of expenditure in the category of final demand to which that expenditure is shifted, total demand in some industries will rise and in other industries will fall. We will bok at both cases in turn. Second, even in industries in which total demand declines, and certainly in ones in which demand expands, there is a shift from defense spending, which was devoted exclusively to home goods, to other demand that is spent partly on imports. This means that there is an additional shift to the left of the home-sector demand curve and shift to the right of the import demand curve. 

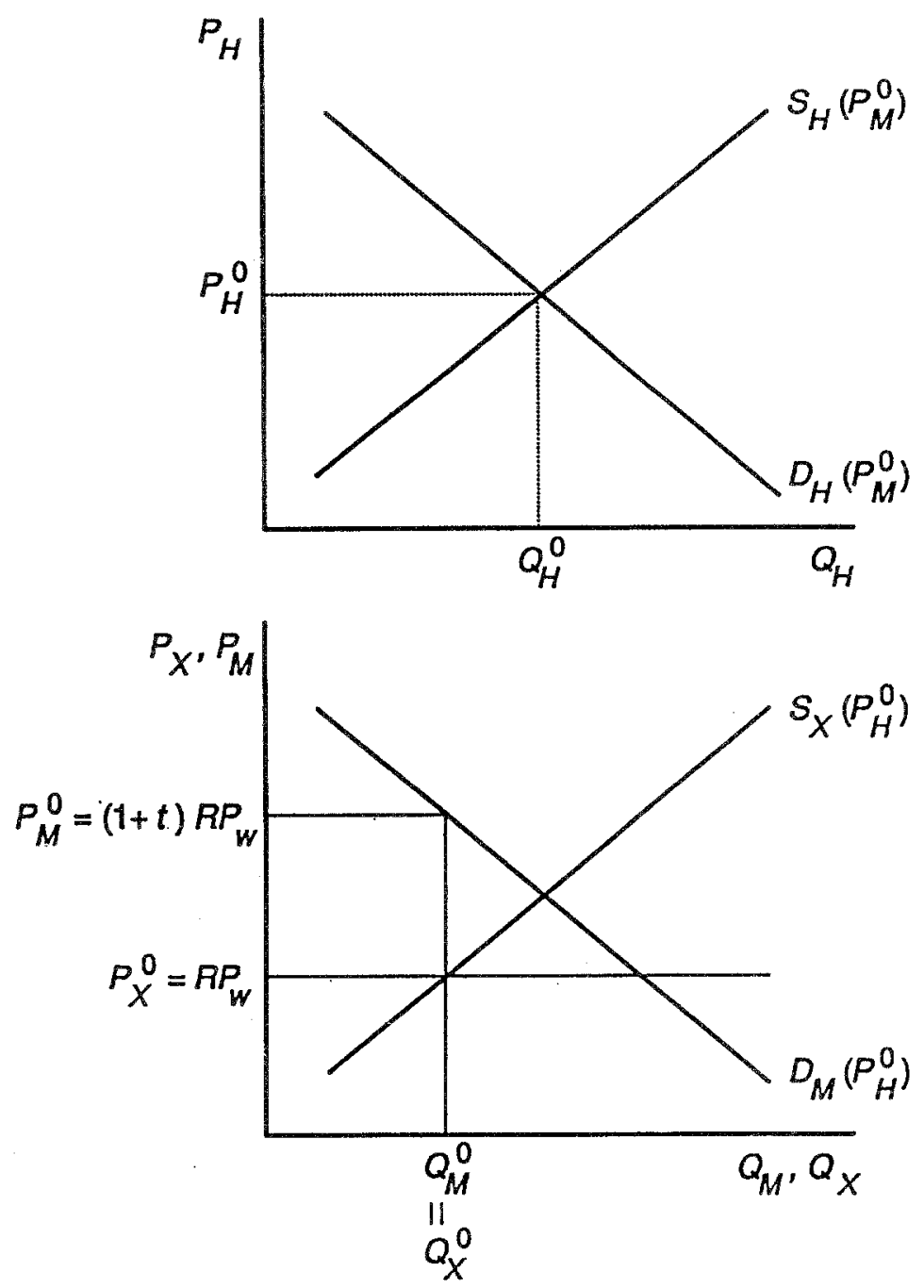

Fig. 1. Partial equilibrium determination of home-sector prices and quantities and of exports and imports. 
Consider, then, an industry in which there has been no defense spending. The cut in defense spending will therefore, at initial prices, unambiguously increase total demand in that industry, as well as increase demands for both imported and home produced goods there. This is shown in Fig. 2 by the shifts of the two demand curves to $D_{\mathrm{H}}^{1}\left(\mathrm{P}_{\mathrm{M}}^{0}\right)$ and $\mathrm{D}_{\mathrm{M}}^{1}\left(\mathrm{P}_{\mathrm{H}}^{0}\right)$. As long as the world price and the exchange rate do not change, the prices of exports and imports in the sector will remain constant. However, the shift in demand in the home sector requires a price increase there, to $\mathrm{P}_{\mathrm{H}}^{1}$, and this induces a further shift in both supply and demand for exports and imports. The demand for imports shifts further to the right, to $D_{M}^{1}\left(P_{H}^{1}\right)$, due to substitution away from higher priced home goods. And the supply of exports shifts to the left, to $\mathrm{S}_{\mathrm{X}}\left(\mathrm{P}_{\mathrm{H}}^{1}\right)$, due to the higher prices of inputs from the home sector. Thus, the result at this point is a rise in output in the home sector, a fall in exports, and a rise in imports.

These results could change, however, if there is a change in prices of exports and imports, though this is not shown in the diagram. If the country is large in the world market, then its increased net demand for imports will raise the world price, $\mathrm{P}_{\mathrm{W}}$. In addition, if the increase in net imports here applies to other industries as well, then the worsening of the trade balance will lead to a depreciation of the currency, i.e., a rise in $\mathrm{R}$, which will also raise the domestic currency prices of traded goods. On the export side, a price increase for either of these reasons will tend to offset the decline in exports shown in Fig. 2 and may even lead exports, in certain sectors, to increase overall.

On the import side, the possible price increase for these two reasons may, in addition, be enhanced by still another possibility. If the industry being considered is covered by a nontariff barrier, then the attempt to increase imports will lead to a rise in the tariff equivalent of the barrier, and thus to a rise in $t$, raising the price of imports still further. Thus, for three reasons $P_{M}$ may rise, and if it does, the changes in Fig. 2 will be further complicated. Such a rise in $\mathrm{P}_{M}$ will lead to a further upward shift in $\mathrm{D}_{\mathrm{H}}$, plus an upward shift in $\mathrm{S}_{\mathrm{H}}$, possibly changing the quantity in the home market from that shown in Fig. 2, and surely increasing the price still further. The additional price increase will also lead to further shifts of supply and demand for trade, and so on. The end result cannot therefore, be obtained with certainty from the diagram. However, all of these secondary shifts seem unlikely to change in a substantial way the results shown in Fig. 2 , which may therefore still be of use in understanding the results of the more complicated interactions captured by the Michigan Model.

Fig. 3 shows the opposite extreme case, where defense expenditure in an industry is cut substantially and only a small amount of new final demand is created in the same industry, thus reducing total demand. 

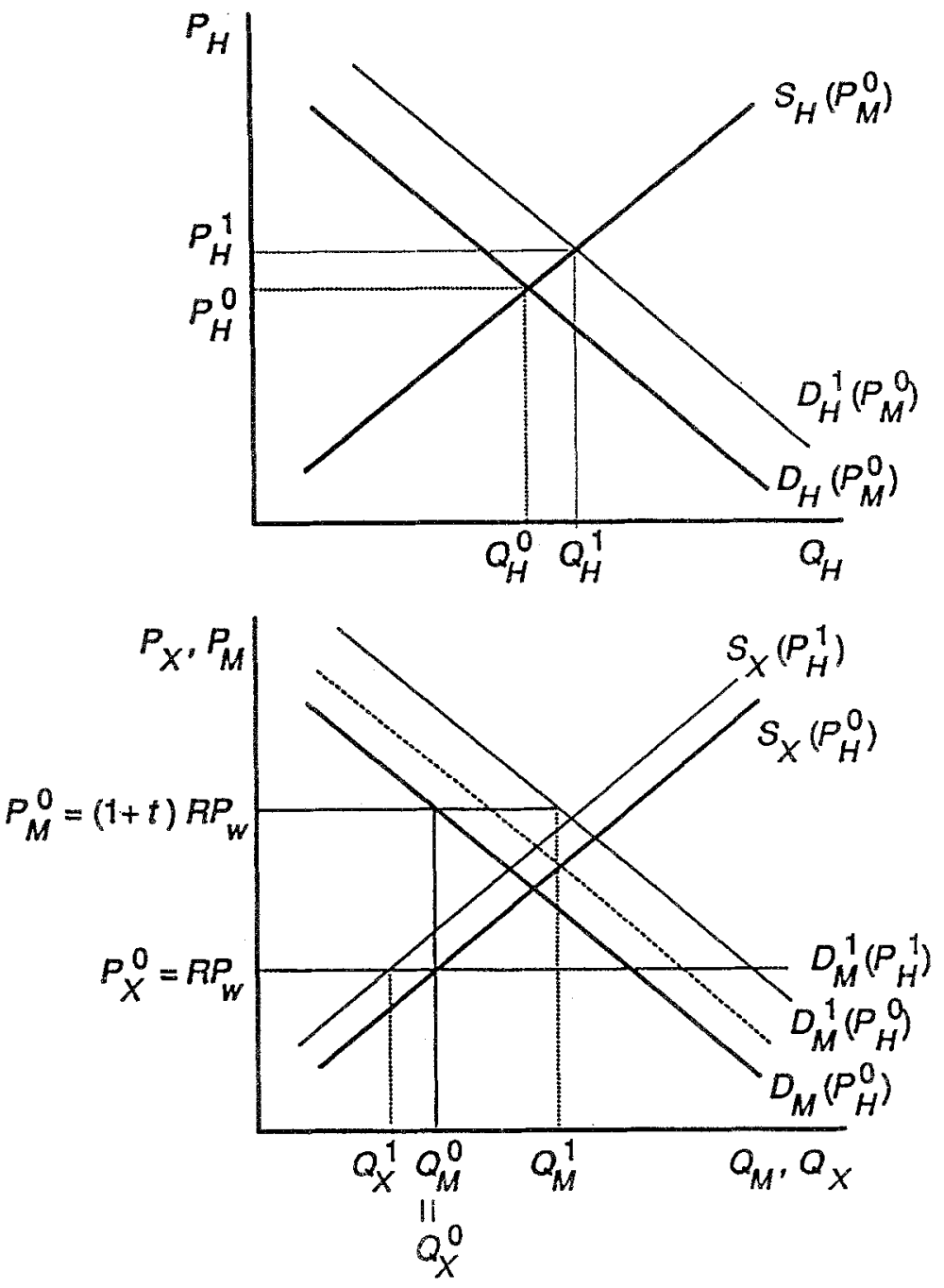

Fig. 2. Partial equilibrium determination of a cut in defense spending in an industry where demand increases. 

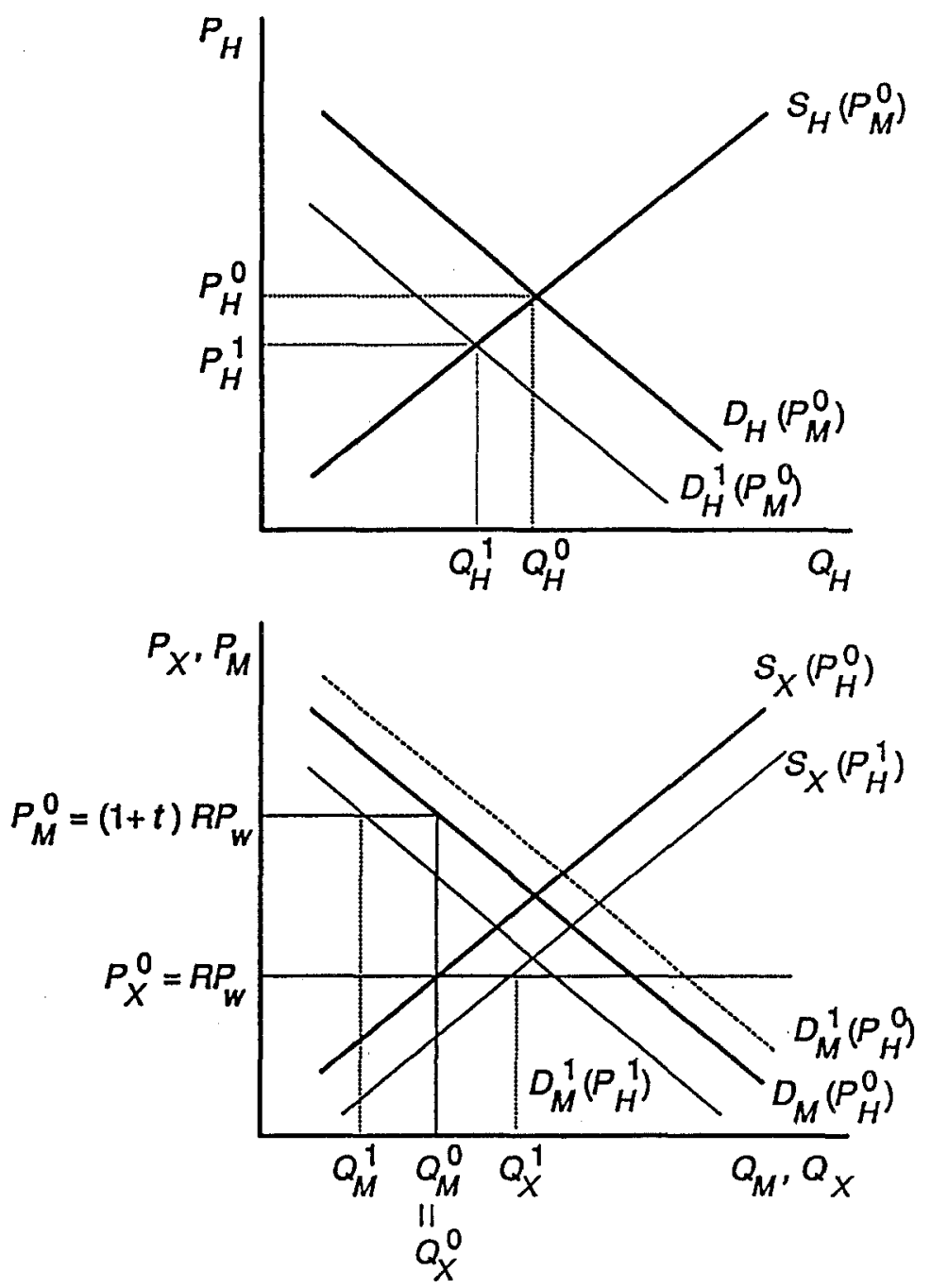

Fig. 3. Partial equlibrium effects of a cut in defense spending in an industry where demand decreases. 
The demand curve in the home sector therefore shifts to the left, to $\mathrm{D}_{\mathrm{H}}^{1}\left(\mathrm{P}_{\mathrm{M}}^{0}\right)$, while the demand curve for imports shifts slightly to the right, to $\mathrm{D}_{\mathrm{M}}^{1}\left(\mathrm{P}_{\mathrm{H}}^{0}\right)$. The price in the home market therefore fails in this case, to $\mathrm{P}_{\mathrm{H}}^{1}$, and this shifts both the supply of exports and the demand for imports down. The results, therefore, are a rise in exports and a fall in imports; assuming, as shown, that the initial increase in mport demand is small compared to the effect of the drop in the home price.

Here again, there could be further adjustment of prices if there are changes in world prices, the exchange rate, or the tariff equivalent of a nontariff barrier; in this case, the effects would tend to go in the opposite direction from what we discussed in connection with Fig. 2. However, since over the entire economy the defense cut replaces spending that was only in home sectors with other spending that goes partly to imports, the case of a currency depreciation that was considered there seems more likely.

To sum up, our theoretical analysis suggests that home-sector prices will rise in some sectors and fall in others due to a shift of expenditure out of defense, with corresponding changes in home-sector outputs. As a first approximation, imports rise and exports fall in sectors where demand expands, while the opposite is likely where demand contracts. However, because of the overall shift toward imports with the cut in defense expenditure, the currency is likely to depreciate, and this tends to raise prices across the board.

It should be evident from our discussion that the effects of a unilateral reduction in military expenditure will depend on a variety of direct and indirect responses to the changes in relative prices that occur within an individual country, as well as between this country and its trading partners. The Michigan Model thus provides a general equilibrium framework for computational analysis of a variety of detailed interactions that will occur at a sectoral level in each of the countries included in the model. When multilateral reductions in military expenditure are analyzed, as in our second scenario, the general equilibrium solution of the model will reflect the sectoral changes that will occur as the countries act in concert rather than unilaterally. We are then able to compare the sectoral effects of unilateral and multilateral reductions in military expenditure and determine to what extent these effects differ in terms of their magnitude and sign (i.e., positive or negative).

\section{Computational results}

The Michigan Model produces results for a wide range of endogenous variables that emerge from the calculations as percentage changes for each of the 29 sectors. Base year data (1980 in this study) are 
then used to compute absolute changes for selected variables, e.g., exports, imports, and employment. We now turn to the results of our two experiments of reductions in military expenditure that are reported in Tables 1-3.

\subsection{Scenario 1: 25 percent unilateral reduction in individual NATO countries}

The aggregate results for both the unilateral and multilateral reductions for the individual NATO countries are presented in Table 1. It appears that a unilateral 25 percent reduction in defense spending is fairly painless in the aggregate for all NATO countries. For the United States in particular, there is a marginal reduction in both exports and imports and only 0.58 percent of the U.S. labor force would experience some dislocation. The effects on the U.S. terms of trade, effective exchange rate, and prices are also quite small.

The changes in overall trade are also quite small in percentage terms, but they are interesting because of the differences among countries. Both exports and imports contract in the United States and several other countries, while they expand in France, Germany, and others. The reason for this difference is to be found in the distribution of military expenditures across sectors.

In France, Germany, and other countries, a large proportion of military expenditures is concentrated in the very labor-intensive nontraded sector ISIC 9-Community, Social, and Personal Services. As a result, when military spending is reduced and shifted to other less laborintensive sectors, the demand for labor falls, causing a drop in the wage. This, in turn, makes exports of these countries slightly more competitive, their exports expand, and exchange rate adjustments cause imports to rise as well. In the United States, Canada, and the United Kingdom, a smaller proportion of military expenditures is in this sector and, with a more broad-based drop in military spending, there is no systematic tendency for the wage to change. In these countries, therefore, the dominant effect arises from shifting spending from nontradable to tradable sectors overall, and that spending tends to displace exports, which then decline. Imports then also fall to maintain balanced trade.

The results in Table 1 are aggregates of the changes that take place in the underlying sectors of each country. Table 2 contains the sectoral employment results for the two experiments. ${ }^{9}$ Looking at the unilateral scenario, it appears that employment decreases significantly in net percentage terms in basic metal industries ( 371 and 372 ), durable goods sectors ( $381,382,383,384$, and $38 \mathrm{~A})$, and community, personal, and social services (ISIC 9 , which includes government employment). ${ }^{10}$ 
Table 1. Aggregate effects on NATO countries due to 25 percent reductions in military spending.

\begin{tabular}{|c|c|c|c|c|c|c|c|c|c|c|}
\hline & & \multicolumn{2}{|c|}{$\begin{array}{l}\text { Change } \\
\text { in Exports }\end{array}$} & \multicolumn{2}{|c|}{$\begin{array}{l}\text { Change } \\
\text { in Imports }\end{array}$} & \multicolumn{2}{|c|}{$\begin{array}{c}\text { Labor } \\
\text { Dislocation }\end{array}$} & \multicolumn{3}{|c|}{$\begin{array}{l}\text { Percent } \\
\text { Change in }\end{array}$} \\
\hline & & $\$$ MILL. & Percent & $\$$ MILL. & Percent & 000 WKA & Percent & $\begin{array}{c}\text { Terms of } \\
\text { Trade }\end{array}$ & Ex. Pate $b$ & Prices ${ }^{c}$ \\
\hline \multirow[t]{2}{*}{$\begin{array}{l}\text { Belgium/ } \\
\text { Luxembourg }\end{array}$} & Unil. & 138.5 & 0.2 & 137.4 & 0.2 & 19.2 & 0.49 & 0.00 & 0.0 & -0.1 \\
\hline & Multi. & 130.3 & 0.2 & 117.3 & 0.2 & 19.3 & 0.49 & -0.03 & 0.1 & -0.1 \\
\hline \multirow[t]{2}{*}{ Canada } & Unil. & -209.0 & -0.3 & -204.1 & -0.3 & 19.7 & 0.18 & 0.01 & 0.0 & 0.0 \\
\hline & Multi. & -264.0 & -0.4 & -208.3 & -0.4 & 21.6 & 0.20 & 0.10 & 0.1 & 0.0 \\
\hline \multirow[t]{2}{*}{ Denmark } & Unil. & 22.6 & 0.1 & 22.7 & 0.1 & 8.9 & 0.37 & 0.00 & 0.0 & -0.1 \\
\hline & Multi. & 11.8 & 0.1 & 26.2 & 0.1 & 9.3 & 0.39 & 0.08 & 0.2 & -0.1 \\
\hline \multirow[t]{2}{*}{ France } & Unil. & 188.6 & 0.2 & 174.3 & 0.1 & 135.2 & 0.64 & -0.01 & 0.0 & -0.1 \\
\hline & Multi. & 259.7 & 0.2 & 206.4 & 0.2 & 138.1 & 0.65 & -0.05 & 0.1 & -0.1 \\
\hline \multirow[t]{2}{*}{ Germany } & Unil. & 224.9 & 0.1 & 201.2 & 0.1 & 103.2 & 0.37 & -0.01 & 0.0 & -0.2 \\
\hline & Multi. & 339.5 & 0.2 & 104.6 & 0.1 & 110.5 & 0.40 & -0.12 & 0.1 & -0.2 \\
\hline \multirow[t]{2}{*}{ italy } & Unil. & 167.2 & 0.2 & 164.4 & 0.2 & 88.6 & 0.43 & 0.00 & 0.0 & -0.2 \\
\hline & Multi. & 204.3 & 0.3 & 172.7 & 0.2 & 95.7 & 0.47 & -0.05 & 0.1 & -0.2 \\
\hline \multirow[t]{2}{*}{ Netheriands } & Unil. & 64.4 & 0.1 & 64.9 & 0.1 & 19.3 & 0.39 & 0.00 & 0.0 & 0.1 \\
\hline & Multi. & 73.7 & 0.1 & 86.9 & 0.1 & 19.1 & 0.39 & 0.02 & -0.1 & 0.1 \\
\hline \multirow[t]{2}{*}{ Norway } & Unil. & 56.7 & 0.3 & 46.6 & 0.3 & 14.3 & 0.75 & 0.00 & 0.0 & 0.0 \\
\hline & Multi. & 63.8 & 0.4 & 48.1 & 0.3 & 15.1 & 0.79 & 0.05 & 0.0 & 0.1 \\
\hline \multirow[t]{2}{*}{ Portugal } & Unil. & 2.1 & 0.0 & 2.1 & 0.0 & 27.5 & 0.70 & 0.00 & 0.0 & 0.2 \\
\hline & Multi. & 12.0 & 0.2 & 12.8 & 0.1 & 27.5 & 0.70 & 0.02 & 0.0 & 0.1 \\
\hline \multirow[t]{2}{*}{ Spain } & Unil. & -27.2 & -0.1 & -27.1 & -0.1 & 35.2 & 0.32 & 0.00 & 0.0 & 0.0 \\
\hline & Multi. & -22.3 & -0.1 & --35.9 & -0.1 & 35.2 & 0.32 & -0.05 & 0.0 & 0.1 \\
\hline \multirow[t]{2}{*}{ Turkey } & Unil. & -19.6 & -0.6 & -19.5 & -0.2 & 38.7 & 0.27 & 0.00 & 0.0 & 0.6 \\
\hline & Multi. & -12.0 & -0.4 & -3.1 & 0.0 & 37.9 & 0.26 & 0.25 & 0.0 & 0.4 \\
\hline \multirow[t]{2}{*}{ United Kingdom } & Unil. & -536.1 & -0.5 & -534.1 & -0.4 & 80.4 & 0.32 & 0.00 & 0.0 & 0.5 \\
\hline & Multi. & -437.3 & -0.4 & -481.4 & -0.4 & 79.5 & 0.32 & -0.05 & -0.5 & 0.5 \\
\hline \multirow[t]{2}{*}{ United States } & Unit. & -858.6 & -0.4 & -679.8 & -0.3 & 578.0 & 0.58 & 0.02 & 0.0 & 0.1 \\
\hline & Multi. & -781.9 & -0.3 & -541.6 & -0.2 & 582.9 & 0.59 & 0.05 & 0.1 & 0.1 \\
\hline
\end{tabular}

Notes: ${ }^{a}$ Refers to sum of changes in the home and export sectors within industries.

b Positive $=$ appreciation.

${ }^{c}$ Index of import and home prices. 
Table 2. Net percentage changes in employment by ISIC sector in the NATO countries for both the 25 percent unilateral and multilateral reductions in military spending.

\begin{tabular}{|c|c|c|c|c|c|c|c|c|c|c|c|c|c|c|c|}
\hline \multirow[b]{2}{*}{ Traded Industries } & & \multicolumn{2}{|c|}{$\begin{array}{c}\text { Belgium } \\
\text { Luxembourg }\end{array}$} & \multicolumn{2}{|c|}{ Canada } & \multicolumn{2}{|c|}{ Denmark } & \multicolumn{2}{|c|}{ France } & \multicolumn{2}{|c|}{ Germany } & \multicolumn{2}{|c|}{ Italy } & \multicolumn{2}{|c|}{ Netheriands } \\
\hline & & Unil. & Multi. & Unil. & Multi. & Unil. & Mults. & Unil. & Mutiti. & Unil. & Multi. & Unil. & Multi. & Unt. & Multi. \\
\hline Agr., For., \& Fishing & (1) & 0.28 & 0.75 & -0.03 & 0.63 & 0.32 & 0.71 & 0.80 & 1.15 & 0.65 & 0.88 & 0.38 & 0.48 & 0.15 & 0.64 \\
\hline Food, Bev., \& Tobacco & (310) & 0.36 & 0.48 & 0.16 & 0.38 & 0.32 & 0.64 & 0.80 & 1.01 & 0.78 & 0.86 & 0.34 & 0.48 & -0.05 & 0.30 \\
\hline Textiles & $(321)$ & 0.06 & 0.26 & -0.20 & -0.24 & 0.02 & -0.01 & 0.42 & 0.83 & 0.06 & 0.35 & 0.20 & 0.50 & -0.64 & -0.60 \\
\hline Wearing Apparel & (322) & 0.28 & 0.84 & 0.18 & 0.28 & -0.24 & -0.08 & 1,30 & 1.76 & 0.67 & 0.95 & 0.54 & 0.94 & -1.51 & -1.16 \\
\hline Leather Products & (323) & 0.15 & 0.41 & -1.34 & -0.36 & -0.43 & -0.24 & 1.06 & 1.74 & 0.05 & 0.52 & 0.14 & 0.59 & 0.25 & 0.71 \\
\hline Footwear & (324) & -0.14 & 0.08 & -0.01 & 0.48 & 0.51 & 0.68 & 1.48 & 1.73 & 0.93 & 1.10 & 0.59 & 0.90 & 0.10 & 0.46 \\
\hline Wood Products & (331) & 0.15 & 0.38 & -0.54 & -0.19 & 0.27 & 0.50 & 0.15 & 0.55 & 0.47 & 0.71 & 0.23 & 0.42 & 0.32 & 0.46 \\
\hline Furniture \& Fixtures & (332) & 0.71 & 0.77 & 0.15 & 0.38 & 0.43 & 0.68 & 0.95 & 1.07 & 0.88 & 1.05 & 0.80 & 0.76 & 0.16 & 0.30 \\
\hline Paper \& Paper Products & (341) & 0.33 & 0.67 & -0.61 & -0.46 & 0.24 & 0.28 & 0.50 & 0.77 & 0.27 & 0.44 & 0.19 & 0.41 & 0.55 & 0.66 \\
\hline Printing \& Publishing & (342) & 0.11 & 0.25 & -0.16 & -0.12 & 0.23 & 0.21 & 0.05 & 0.13 & 0.09 & 0.15 & -0.04 & 0.05 & 0.40 & 0.40 \\
\hline Chemicals & (35A) & 0.16 & 0.32 & -0.63 & -0.54 & 0.17 & 0.09 & 0.31 & 0.40 & -0.04 & 0.22 & 0.13 & 0.27 & 0.28 & 0.25 \\
\hline Petrol, \& Rel. Prod. & (35B) & -0.61 & -0.38 & -0.38 & -0.38 & -1.23 & -1.25 & 0.42 & 0.42 & 1.35 & 1.29 & 0.47 & 0.47 & 0.45 & 0.41 \\
\hline Rubber Products & (355) & 0.32 & 0.20 & -1.12 & -1.70 & 0.28 & -0.03 & 0.13 & 0.00 & 0.18 & 0.21 & 0.19 & 0.10 & 0.55 & 0.10 \\
\hline Nonmetallic Min. Prod. & (36A) & 0.87 & 0.94 & -0.21 & -0.26 & 0.82 & 0.45 & 0.94 & 0.93 & 0.59 & 0.78 & 0.89 & 0.97 & 0.80 & 0.61 \\
\hline Glass \& Glass Products & (362) & 1.16 & 1,22 & -0.77 & -0.96 & 0.69 & 0.09 & 0.63 & 0.63 & 0.47 & 1.16 & 0.56 & 0.75 & 0.52 & 0.31 \\
\hline Iron \& Steel & (371) & 0.58 & 0.34 & -0.67 & -1.08 & 0.13 & -0.03 & 0.20 & 0.08 & 0.02 & 0.00 & 0.06 & -0.03 & 0.33 & 0.02 \\
\hline Nonferrous Metals & $(372)$ & 0.94 & 1.00 & -0.80 & -1.00 & 0.18 & -0.03 & 0.12 & 0.06 & -0.01 & 0.08 & 0.14 & 0.16 & 0.30 & 0.06 \\
\hline Metal Products & $(381)$ & 0.35 & 0.38 & -0.57 & -0.66 & 0.41 & 0.36 & 0.46 & 0.44 & 0.23 & 0.31 & 0.25 & 0.33 & 0.42 & 0.34 \\
\hline Nonelectric Machinery & (382) & -0.25 & -0.08 & -1.00 & -0.96 & 0.09 & 0.08 & 0.07 & 0.09 & 0.40 & 0.50 & 0.16 & 0.37 & -0.15 & -0.16 \\
\hline Electric Machinery & (383) & -0.18 & -0.39 & -1.22 & -1.57 & -0.47 & -0.92 & -1.05 & -1.33 & 0.08 & -0.16 & -0.36 & -0.57 & -0.02 & -0.36 \\
\hline Transportation Equip. & (384) & 0.19 & -0.69 & -1.41 & -2.62 & -1.10 & -2.88 & -1.36 & -2.01 & -0.46 & -0.87 & -0.78 & -1.77 & -0.55 & -1.21 \\
\hline Miscellaneous Manufac. & (38A) & 0.21 & -0.11 & -1.29 & -1.88 & 0.29 & -0.41 & 0.44 & 0.13 & -0.50 & -0.48 & 0.28 & 0.06 & 0.42 & -0.10 \\
\hline Mining \& Quarrying & (2) & 0.98 & 0.29 & -0.58 & -0.47 & 0.47 & 0.47 & 0.56 & 0.66 & 0.05 & 0.24 & 0.10 & 0.38 & 1.18 & 1,30 \\
\hline Total Traded & & 0.26 & 0.28 & -0.46 & -0.41 & 0.16 & 0.14 & 0.30 & 0.34 & 0.22 & 0.26 & 0.19 & 0.20 & 0.10 & 0.12 \\
\hline \multicolumn{16}{|l|}{ Nontraded Industries } \\
\hline Electric, Gas \& Water & (4) & 0.72 & 0.65 & -0.27 & -0.30 & 0.78 & 0.78 & 0.96 & 0.91 & 0.62 & 0.60 & 0.27 & 0.25 & 0.81 & 0.78 \\
\hline Construction & (5) & 0.88 & 0.87 & 0.17 & 0.17 & 0.73 & 0.77 & 1.07 & 1.05 & .85 & 0.81 & 0.68 & 0.67 & 0.57 & 0.58 \\
\hline Wholesale \& Ret. Trade & (6) & 1.27 & 1.24 & 0.27 & 0.24 & 0.92 & 0.91 & 1.40 & 1.37 & 0.77 & 0.74 & 1.18 & 1.15 & 0.95 & 0.94 \\
\hline Transp., Stor., \& Com. & $(7)$ & 0.27 & 0.26 & -0.46 & -0.49 & 0.24 & 0.25 & 0.39 & 0.38 & 0.25 & 0.24 & 0.23 & 0.21 & 0.42 & 0.41 \\
\hline Fin., Ins. \& Real Est. & (B) & 0.62 & 0.61 & 0.54 & 0.50 & 0.92 & 0.93 & 1.24 & 1.21 & 1.23 & 1.19 & 0.40 & 0.38 & 0.73 & 0.72 \\
\hline Comm., Soc. \& Pers. Serv. & (9) & -1.58 & -1.57 & 0.21 & 0.20 & -0.82 & -0.90 & -2.09 & -2.10 & -1.15 & -1.18 & -1.80 & -1.81 & -1.05 & -1.06 \\
\hline Total Nontraded & & -0.09 & -0.10 & 0.15 & 0.14 & -0.06 & -0.05 & -0.14 & -0.16 & -0.12 & -0.15 & -0.12 & -0.12 & -0.03 & -0.04 \\
\hline Total, All industries & & 0.01 & 0.01 & 0.00 & 0.00 & 0.00 & 0.00 & 0.01 & 0.01 & 0.00 & 0.00 & 0.01 & 0.01 & 0.00 & 0.00 \\
\hline
\end{tabular}

(Continued) 
Table 2. (Continued)

\begin{tabular}{|c|c|c|c|c|c|c|c|c|c|c|c|c|c|}
\hline \multirow[b]{2}{*}{ Traded Indusrtries } & & \multicolumn{2}{|c|}{ Norway } & \multicolumn{2}{|c|}{ United Kingdom } & \multicolumn{2}{|c|}{ United States } & \multicolumn{2}{|c|}{ Portugal } & \multicolumn{2}{|c|}{ Spain } & \multicolumn{2}{|c|}{ Turkay } \\
\hline & & Unil. & Multi. & Unil. & Multi, & Unil. & Mutti. & Unil. & Butt. & Unit. & Muki. & Unil. & Muthi \\
\hline Agf., Fot, \& Fishing & (1) & 1.78 & 2.66 & 0.13 & 0.29 & 1.17 & 1.41 & 0.81 & 0.83 & 0.35 & 0.40 & 0.35 & 0.37 \\
\hline Food, Bev, \& Tobecco & $(310)$ & 0.10 & 0.24 & 0.44 & 0.48 & 1.45 & 9.50 & 0.85 & 1.02 & 0.33 & 0.39 & 0.17 & 0.25 \\
\hline Texiles & (321) & 0.94 & 1.54 & -0.67 & -0.33 & 0.32 & 0.42 & 0.18 & 0.26 & 0.26 & 0.27 & -0.10 & -0.07 \\
\hline Wearing Apparel & (322) & 0.57 & 1.40 & -0.43 & -0.10 & 0.88 & 0.93 & 1.64 & 1.82 & 0.49 & 0.49 & -0.04 & 0.03 \\
\hline Leather Products & (323) & 1.84 & 4.53 & -0.58 & -0.21 & 0.26 & 0.58 & 0.67 & 0.74 & 0.19 & 0.29 & 0.02 & 0.10 \\
\hline Footwear & (324) & -0.10 & 0.43 & 0.26 & 0.41 & 1.37 & 1.45 & 1.43 & 1.53 & 0.40 & 0.42 & 0.60 & 0.57 \\
\hline Wood Products & (331) & 0.98 & 1.15 & -0.17 & 0.21 & 0.49 & 0.58 & 0.25 & 0.44 & 0.30 & 0.35 & -0.07 & -0.06 \\
\hline Furniture \& Fxtures & (332) & 0,66 & 0.76 & 0.04 & 0.32 & 1.34 & 1.41 & 1.38 & 1.34 & 0.55 & 0.54 & 0.50 & 0.48 \\
\hline Paper \& Paper Products & (3A1) & 0.22 & 0.53 & -0.80 & -0.39 & 0.43 & 0.50 & 0.80 & 0.82 & 0.05 & 0.08 & -0.04 & -0.08 \\
\hline Printing \& Publishing & $(342)$ & 0.39 & 0.34 & -0.05 & 0.02 & 0.58 & 0.59 & -0.07 & -0.12 & -0.01 & -0.01 & -0.02 & -0.06 \\
\hline Chemicais & (35A) & 0.34 & 0.41 & -0.44 & -0.21 & -0.17 & -0.14 & 0.13 & 0.10 & -0.00 & -0.07 & 0.15 & 0.02 \\
\hline Potrol. \& fiel. Prod. & (358) & -0.05 & 0,01 & -5.60 & -5.32 & 0.41 & 0.40 & -0.66 & -0.24 & -0.88 & -1.04 & -0.14 & -0.08 \\
\hline Rubber Products & (355) & 0.85 & 0.39 & -1.48 & -1.65 & -0.61 & -0.72 & 0.20 & 0.21 & -0.27 & -0.32 & -0.03 & -0.08 \\
\hline Nonmetallic Min, Prod. & (36A) & 0.81 & 0.70 & -0.33 & -0.26 & 0.44 & 0.42 & 0.73 & 0.74 & 0.32 & 0.30 & -0.08 & -0.07 \\
\hline Gless Gless Products & (362) & 0.47 & 0.24 & -1.72 & -1.70 & -0.35 & -0.40 & 0.37 & 0.36 & -0.01 & -0.03 & 0.14 & 0.11 \\
\hline Iron \& Stesi & (371) & 1.43 & 0.80 & -0.95 & -0.99 & -0.96 & -1.01 & 0.33 & 0.25 & 0.02 & -0.03 & -0.15 & -0.23 \\
\hline Nonferrous Metais & (372) & 0.47 & 0.24 & -2.35 & -1.84 & -1.44 & -1.46 & 1.00 & 0.82 & -0.09 & -0.18 & -0.32 & -0.37 \\
\hline Metal Products & $(381)$ & 0.75 & 0.68 & -0.64 & -0.59 & -0.71 & -0.73 & 0.64 & 0.65 & $0.1 \mathrm{~A}$ & 0.13 & 0.00 & -0.05 \\
\hline Nonelectric Machinery & (382) & 0.15 & 0.14 & -0.24 & -0.08 & -0.59 & -0.64 & -0.08 & -0.03 & -0.13 & -0.12 & -0.19 & -0.25 \\
\hline Electric Machinery & (383) & -0.73 & -1.24 & -1.80 & -2.09 & -3.29 & -3.38 & -0.16 & -0.22 & -0.37 & -0.40 & -0.83 & -0.87 \\
\hline Transportation Equip. & $(384)$ & -0.31 & -1.05 & -1.72 & -2.33 & -2.86 & -3.07 & -0.18 & -0.24 & -0.38 & -0.45 & -0.38 & -0.38 \\
\hline Miscellangous Manufac. & (3BA) & 0.28 & -0.08 & -1.32 & -1.44 & -2.59 & -2.67 & 0.47 & 0,39 & 0.07 & 0.01 & -0.14 & -0.19 \\
\hline Mining \& Quarrying & (2) & 4.37 & 5.37 & -0.61 & -0.21 & 0.19 & 0.29 & -3.59 & -3.49 & -0.28 & -0.22 & 0.50 & -0.11 \\
\hline Tolal Traded & & 0.74 & 0.93 & -0.70 & -0.68 & -0.46 & -0.44 & 0.64 & 0.68 & 0.20 & 0.22 & 0.29 & 0.31 \\
\hline \multicolumn{14}{|l|}{ Nontraded industries } \\
\hline Electric, Gas \& Water & (4) & 1.69 & 1.44 & -1.33 & -1.25 & 1.13 & 1.12 & 0.10 & 0.11 & 0.04 & 0.00 & -0.08 & -0.13 \\
\hline Construction & (5) & 0.99 & 0.94 & 0.42 & 0.39 & 0.71 & 0.70 & 0.67 & 0.67 & 0.35 & 0.33 & -0.07 & -0.08 \\
\hline Wholesale \& PAt. Trede & (6) & 1.65 & 1.53 & 0.57 & 0.55 & 1.30 & 1.29 & 2.00 & 1.91 & 0.67 & 0.65 & 0.28 & 0.24 \\
\hline Trensp., Stor., \& Com. & (7) & 0.68 & 0.63 & -0.88 & -0.88 & 0.23 & 0.22 & 0.41 & 0.40 & 0.12 & 0.11 & 0.15 & 0.15 \\
\hline Fin., Ins. \& Real Est. & (e) & 0.77 & 0.72 & 0.17 & 0.16 & 1.49 & 1.48 & 1.25 & 1,19 & 0.84 & 0.81 & 0.58 & 0.47 \\
\hline Comm, Soc. \& Pers. Sen. & (9) & -2.35 & -2.44 & 0.55 & 0.55 & -1.08 & -1.08 & $-3.8 i$ & -3.67 & -1.79 & -1.80 & -2.08 & -2.12 \\
\hline Total Nontraded & & -0.28 & -0.35 & 0.31 & 0.31 & 0.17 & 0.16 & -0.72 & -0.76 & -0.16 & -0.18 & -0.74 & -0.79 \\
\hline Total, All Industries & & 0.01 & 0.02 & 0.00 & 0.00 & 0.01 & 0.01 & 0.02 & 0.02 & 0.00 & 0.00 & 0.00 & 0.00 \\
\hline
\end{tabular}

The sectoral results for the other NATO countries are qualitatively similar to those for the U.S. in the sense of being relatively small on the whole and being concentrated in metal products and durable 
goods. The results are by no means uniform, however, and apparently reflect some noteworthy differences in the sectoral incidence of military spending and technological differences in input-output structures.

\subsection{Scenario 2: 25 percent multilateral reduction in NATO countries combined}

Here we summarize the results of a proportional shift of 25 percent of military expenditures across all categories of final demand for all the NATO countries combined.

The aggregate results of the multilateral reductions for the individual NATO countries are listed in Table 1 together with the results of the unilateral reductions. The aggregate results of the multilateral reductions are listed in Table 3 for all 34 countries included in the Michigan Model. The sectoral results of the multilateral reductions for the individual NATO countries are listed in Table 2 together with the sectoral results of the unilateral reductions.

For the United States, it appears that, in the aggregate, a multilateral reduction in military spending in the NATO countries has a somewhat smaller impact on U.S. exports and imports than does a unilateral reduction. ${ }^{11}$ The labor dislocation is virtually the same in the two cases while the U.S. terms of trade improve somewhat more with the multilateral reductions. The results for the United Kingdom are similar to those for the United States. For the other NATO countries, there are numerous instances in which the multilateral reductions have a somewhat larger trade and labor dislocation impact than the unilateral reductions in military expenditures. But in all cases, these changes are relatively small in percentage terms.

The aggregate results in Table 3, which includes all 34 countries covered in the Michigan Model, indicate that the non-NATO countries would not be particularly affected by the unilateral/multilateral reductions in NATO country military expenditures.

The sectoral results, which are listed in Table 2, indicate slightly larger net percentage changes in employment for the multilateral reductions. But on the whole, the results for both experiments are qualitatively very similar.

\section{Conclusions and implications}

In the long run, a reduction in defense spending is generally regarded to have a positive impact on an economy. In the short run, however, a reduction in defense outlays could result in unemployment and 
Table 3. Summary of effects on the major industrialized and developing countries due to a 25 percent multilateral reduction in military expenditures in each of the NATO countries.

\begin{tabular}{|c|c|c|c|c|c|c|c|c|c|}
\hline & \multicolumn{2}{|c|}{$\begin{array}{l}\text { Value of Change } \\
\text { in Exports }\end{array}$} & \multicolumn{2}{|c|}{$\begin{array}{l}\text { Value of Change } \\
\text { in Imports }\end{array}$} & \multicolumn{2}{|c|}{$\begin{array}{l}\text { Gross Change } \\
\text { in employment }\end{array}$} & \multirow[t]{2}{*}{$\begin{array}{l}\% \text { Change in } \\
\text { Terms of Trade }\end{array}$} & \multirow{2}{*}{$\begin{array}{c}\text { Pct Change } \\
\text { in Eff. } \\
\text { Ex. Rate }\end{array}$} & \multirow{2}{*}{$\begin{array}{c}\text { Pet Change } \\
\text { in } \\
\text { Prices }\end{array}$} \\
\hline & $\$$ Mill. & Pct & \$ Mill. & Pct & $000 \mathrm{Wkr}$ & Pct & & & \\
\hline \multicolumn{10}{|c|}{ Industrialized Countries } \\
\hline Australia & 66.7 & 0.3 & 10.4 & 0.1 & 5.8 & 0.09 & 0.23 & 0.0 & 0.1 \\
\hline Austria & -0.4 & -0.0 & 3.2 & 0.0 & 3.0 & 0.10 & -0.00 & -0.1 & 0.0 \\
\hline Canada & -264.0 & -0.4 & -208.3 & -0.4 & 21.6 & 0.20 & 0.10 & 0.1 & -0.0 \\
\hline \multicolumn{10}{|c|}{ European Community } \\
\hline $\begin{array}{l}\text { Beigium/ } \\
\text { Luxembourg }\end{array}$ & 130.3 & 0.2 & 117.3 & 0.2 & 19.3 & 0.49 & -0.03 & 0.1 & -0.1 \\
\hline Denmark & 11.8 & 0.1 & 28.2 & 0.1 & 9.3 & 0.39 & 0.08 & 0.2 & -0.1 \\
\hline France & 259.7 & 0.2 & 206.4 & 0.2 & 138.1 & 0.65 & -0.05 & 0.1 & -0.1 \\
\hline Germany & 339.5 & 0.2 & 104.6 & 0.1 & 110.5 & 0.40 & -0.12 & 0.1 & -0.2 \\
\hline Iraland & -5.4 & -0.1 & 3.0 & 0.0 & 0.7 & 0.06 & 0.09 & 0.4 & -0.0 \\
\hline Italy & 204.3 & 0.3 & 172.7 & 0.2 & 95.7 & 0.47 & -0.05 & 0.1 & -0.2 \\
\hline Netherlands & 73.7 & 0.1 & 86.9 & 0.1 & 19.1 & 0.39 & 0.02 & -0.1 & 0.1 \\
\hline United Kingdom & -437.3 & -0.4 & -481.4 & -0.4 & 79.5 & 0.32 & -0.05 & -0.5 & 0.5 \\
\hline Total EC & 576.7 & 0.1 & 235.8 & 0.0 & 472.2 & 0.44 & -0.06 & -0.0 & -0.0 \\
\hline Finland & 23.1 & 0.2 & 3.6 & 0.0 & 2.0 & 0.09 & 0.05 & 0.0 & 0.1 \\
\hline Japen & 253.0 & 0.2 & -184.0 & -0.1 & 28.2 & 0.05 & -0.32 & -0.2 & 0.1 \\
\hline New Zealand & -4.9 & -0.1 & 12.0 & 0.2 & 1.0 & 0.08 & 0.29 & 0.3 & -0.0 \\
\hline Nonway & 63.8 & 0.4 & 48.1 & 0.3 & 15.1 & 0.79 & 0.05 & 0.0 & 0.1 \\
\hline Sweden & -5.6 & -0.0 & 5.1 & 0.0 & 2.8 & 0.07 & -0.05 & 0.0 & 0.0 \\
\hline Switzerland & -80.2 & -0.2 & 2.2 & 0.0 & 2.6 & 0.08 & -0.01 & 0.1 & -0.0 \\
\hline United States & -781.9 & -0.3 & -541.6 & -0.2 & 582.9 & 0.59 & 0.05 & 0.1 & 0.1 \\
\hline Total Industrialized & -133.7 & -0.0 & -613.4 & -0.0 & 1137.2 & 0.37 & -0.04 & -0.0 & 0.0 \\
\hline \multicolumn{10}{|c|}{ Developing Countries } \\
\hline Argentina & 28.3 & 0.3 & 63.5 & 0.6 & 7.9 & 0.08 & 0.38 & 0.0 & -0.1 \\
\hline Brazil & 122.2 & 0.6 & 143.0 & 0.6 & 50.9 & 0.12 & 0.10 & 0.0 & -0.3 \\
\hline Chile & 20.2 & 0.4 & 24.4 & 0.3 & 1.9 & 0.06 & 0.08 & 0.0 & 0.1 \\
\hline Colombia & 17.5 & 0.4 & 33.6 & 0.7 & 7.2 & 0.13 & 0.34 & 0.0 & -0.1 \\
\hline Greece & 29.7 & 0.5 & 43.8 & 0.4 & 4.3 & 0.11 & 0.17 & 0.0 & -0.1 \\
\hline Hong Kong & -0.8 & -0.0 & -2.5 & -0.0 & 2.2 & 0.11 & -0.02 & 0.1 & -0.0 \\
\hline India & 13.9 & 0.2 & 18.3 & 0.3 & 18.4 & 0.01 & 0.08 & 0.0 & -0.0 \\
\hline
\end{tabular}

(Continued) 
Table 3. (Continued)

\begin{tabular}{|c|c|c|c|c|c|c|c|c|c|}
\hline & \multicolumn{2}{|c|}{$\begin{array}{l}\text { Vaiue of Change } \\
\text { in Exports }\end{array}$} & \multicolumn{2}{|c|}{$\begin{array}{l}\text { Value of Change } \\
\text { in Imports }\end{array}$} & \multicolumn{2}{|c|}{$\begin{array}{l}\text { Gross Change } \\
\text { in employment }\end{array}$} & \multirow[t]{2}{*}{$\begin{array}{l}\text { \% Change in } \\
\text { Terms of Trade }\end{array}$} & \multirow{2}{*}{$\begin{array}{l}\text { Pet Change } \\
\text { in Eff. } \\
\text { Ex. Rate }\end{array}$} & \multirow{2}{*}{$\begin{array}{c}\text { Pet Change } \\
\text { in } \\
\text { Prices }\end{array}$} \\
\hline & $\$$ Mill. & Pct & $\$$ Mill. & Pct & $000 \mathrm{Wkr}$ & $\mathrm{Pct}$ & & & \\
\hline |srael & -3.2 & -0.1 & 1.5 & 0.0 & 0.7 & 0.05 & 0.07 & 0.1 & -0.0 \\
\hline South Korea & 6.5 & 0.0 & -5.7 & -0.0 & 4.4 & 0.03 & -0.06 & 0.0 & 0.0 \\
\hline Mexico & 1.0 & 0.0 & 16.2 & 0.1 & 5.4 & 0.03 & 0.08 & 0.0 & 0.0 \\
\hline Portugal & 12.0 & 0.2 & 12.8 & 0.1 & 27.5 & 0.70 & 0.02 & 0.0 & 0.1 \\
\hline Singapore & 21.5 & 0.1 & 5.8 & 0.0 & 0.5 & 0.05 & 0.02 & 0.0 & 0.0 \\
\hline Spain & -22.3 & -0.1 & -35.9 & -0.1 & 35.2 & 0.32 & -0.05 & 0.0 & 0.1 \\
\hline Taiwan & 0.0 & 0.1 & 1.9 & 0.0 & 0.3 & 0.00 & 0.01 & 0.0 & -0.0 \\
\hline Turkey & -12.0 & -0.4 & -3.1 & -0.0 & 37.9 & 0.26 & 0.25 & 0.0 & 0.4 \\
\hline Yugoslavia & 5.0 & 0.0 & 3.6 & 0.0 & 0.8 & 0.01 & -0.03 & -0.0 & 0.0 \\
\hline $\begin{array}{l}\text { Total } \\
\text { Developing }\end{array}$ & 239.8 & 0.1 & 321.2 & 0.1 & 205.6 & 0.04 & 0.09 & 0.0 & -0.0 \\
\hline All Countries & 106.1 & 0.0 & -292.2 & -0.0 & 1342.7 & 0.12 & -0.02 & -0.0 & 0.0 \\
\hline
\end{tabular}

Notes: a Refers to sum of changes in the home and export sectors within industries.

b Positive = appreciation.

c Index of import and home prices.

adjustment pressures in at least some sectors of the economy. In order to facilitate a smooth transition, government assistance, if deemed necessary, should be pointed in the right direction.

Our results suggest that, while the impacts of a 25 percent unilateral or multilateral reduction in military expenditures do not appear to be large in the aggregate,$^{12}$ the negative sectoral net employment impacts appear to be concentrated in certain specific sectors, such as basic metals and metal products, durable goods industries, and community, social, and personal services. Depending on the magnitude of the reduction in military expenditures and the time horizon involved with respect to adjustment, these particular sectors might be in need of assistance in the event that reduced military spending were in fact carried out. ${ }^{13}$ Indeed, the availability of such assistance could be important in garnering political support for the military expenditure reductions.

\section{Acknowledgments}

Earlier versions of this paper were presented at the Annual Meeting of the American Economic Association, joint session with the 
PSSI/ECAAR, Conflict and Peace Economics V: "Models Relating to Military Expenditures, Their Reduction and Terrorism," New Orleans, January 4, 1992; and at the Tinbergen Institute and the Dutch/Flemish Association of Economists for Peace, Conference on "Economics of International Security," The Hague, May 21-23, 1992.

Financial assistance was provided in part by a grant from the Ford Foundation in support of a program of research in trade policy in the Institute of Public Policy Studies at the University of Michigan. We wish to thank Seong-Hum Yun and Alan K. Fox for computational assistance and Judith Jackson for typing and editorial assistance.

\section{Notes}

1. As will become clear from the discussion that follows, we can use our modeling framework to analyze increases, as well as reductions, in military spending.

2. There may, of course, be other effects at both the micro and aggregate levels that our modeling approach cannot capture. These effects include the dynamics of adjustment in goods and factor markets and possible impacts working through financial markets and changes in aggregate savings and investment behavior. This suggests the need for a broader and more integrated modeling effort, which unfortunately is beyond our capability at present.

3. The countries and industries are listed in Table 3. It shouid be noted that the European Community is represented as the EC-9, and that Greece, Portugal, and Spain are listed in the group of developing countries. Also, the results for Germany refer only to West Germany, and those for Yugoslavia refer to that entire nation.

4. As will be discussed below, our sector aggregates may obscure technological differences in the production of military and nonmilitary goods in certain sectors.

5. A fourth possibility is that the government could contract the money supply (or reduce its rate of expansion). The results would then depend on what accompanying changes maintain full employment. If there were a general deflation of prices and wages, this would increase the real value of all components of spending across the board, similar to the proportional expansion assumed here.

6. By a unilateral reduction, we mean a reduction in a given NATO country, while other NATO countries continue military spending at the old level. A multilateral reduction means a coordinated reduction at the same time in all of the NATO countries.

7. See Haveman, Deardorf, and Stern (1992) for further elaboration of the procedure used here.

8. Of course, inputs from other sectors are typically more important than inputs from the same industry represented here. Other than this input-price effect, the Michigan Model does not include any direct effect of the home price on export supply, or vice versa, since capital is assumed specific to each subsector and labor can be hired independently in each.

9. The sectoral changes in exports and imports are available from the authors on request.

10. It should be noted that military personnel are included in sector 9 , which means that we assume the military employs workers in the same proportion as all other components of sector 9 . The results presented will thus be understated or overstated, depending on the difference in labor as a fraction of spending in each component 
of sector 9. Nonetheless, correction for these inaccuracies would not change the qualitative nature of the results.

11. With a multilateral reduction in spending, all-NATO countries shift spending toward tradable sectors, which raises their world prices relative to nontradables. This tends to expand trade in all of the countries, compared to the effects under unilateral military spending reductions. Thus in the United States, when trade falls, it falls by less in the multilateral case, while in France and Germany, when trade expands, it expands by more.

12. Dunne (1991) reaches similar conclusions to ours using an empirical analysis based on regression methods, as well as citing the results of earlier studies based on input-output methods.

13. See: Fox and Stern (1993) for a more detailed analysis of the effects of reductions in NATO military expenditures on U.S. employment by sector/occupation/region and for calculation of associated wage losses.

\section{References}

Barker, Terry, Paul Dunne, and Ron Smith (1990) "The Peace Dividend and the U.K. Economy," unpublished manuscript, University of Cambridge, United Kingdom.

Deardorf, Alan V. and Robert M. Stern (1986) The Michigan Model of World Production and Trade: Theory and Applications. Cambridge: MIT Press.

Deardorff, Alan V. and Robert M. Stern (1990) Computational Analysis of Global Trading Arrangements. Ann Arbor: University of Michigan Press.

Dunne, J. Paul (1991) "Conversion and Employment: A Comparative Assessment," DAE Working Paper No. 9116 (August), Department of Applied Economics, University of Cambridge.

Filip-Kohn, R., R. Krengel, and D. Schumacher (1980) "Macro-Economic Effects of Disarmament Policies on Sectoral Production and Employment in the Federal Republic of Germany, with Special Emphasis on Development Policy Issues," German Institute for Economic Research, Berlin.

Fox, Alan K. and Robert M. Stern (1993) "Effects of Reductions in NATO Military Expenditures on U.S. Employment by Sector/Occupation/Region," The World Economy. Forthcoming.

Haveman, Jon D., Alan V. Deardorff, and Robert M. Stern (1992) "Some Economic Effects of Unilateral and Multilateral Reductions in Military Expenditures in the Major Industrialized and Developing Countries," Journal of Conflict Management and Peace Science 12, 47-78.

Herring, P.G. (1989) "The Economic Impact of Defence Expenditures: FY 1987/88," Centre for Studies in Defence Resources Management, Report \#18, National Defence College of Canada, Kingston, Canada.

Leontief, Wassily W. and Faye Duchin (1983) Military Spending: Facts and Figures, Worldwide Implications and Future Outlook. New York: Oxford University Press.

Steuerle, Eugene C. and Susan Wiener (1990) "Spending the Peace Dividend: Lessons From History," Urban Institute Policy Paper, Washington, D.C.

United States Arms Control and Disarmament Agency (1990) World Military Expenditures and Arms Transfers 1989. Washington: U.S. Government Printing Office.

United States Department of Commerce, (1990) The Survey of Current Business (January), Washington: Bureau of Economic Analysis. 